\title{
The military and democracy in Bangladesh
}

\section{Abstract for chapter 7}

\section{Author: Emajuddin Ahamed}

While the institutional framework for parliamentary democracy has been set up in Bangladesh, the author questions whether it can sustain democratic order. In answer, he examines the nature of the political system at independence and the emergence of the military as the ruling elite.

A high level of politicisation of the armed forces is evident, exacerbated by the training within the British Indian army of the Bangladesh Army to be 'the custodian of law and order' essentially setting it in opposition to the national interests and demands. The Bangladesh Army inherited both the institutional framework of its British Indian and Pakistan Army predecessors as well as their orientation against civilian rule and their sensitivity to political power.

The author concludes that the prospects for democracy are likely only if the political parties can maintain the emerging consensus and politics of compromise.

Keywords

Awami League, Jatiya Sangsad (House of the Nation), militia, Muslim League, parliamentary democracy, praetorian polity 


\title{
7
}

\section{THE MILITARY AND DEMOCRACY IN BANGLADESH}

\author{
Emajuddin Ahamed
}

Bangladesh is at a crossroads in its march towards democratic order. Though it started its political journey with a parliamentary system after independence, it failed to sustain it; slowly but steadily the parliamentary government degenerated into an authoritarian system. As Bangladesh completes its twenty years of independence it also completes thirteen years of military rule or governments dominated by the military.

In late 1990, however, the political situation altered dramatically. Autocratic rule was ultimately defeated by a popular uprising, and General Ershad had to resign. Under the close supervision of a caretaker government headed by Chief Justice Shahabuddin Ahmed, installed after the resignation of General Ershad, a free, fair and neutral general election was held on 27 February 1991. A truly representative Jatiya Sangsad (House of the Nation) thus came into being. In a bid to democratise the polity in Bangladesh the Sangsad substantially amended the constitution. A parliamentary system of government was proposed in the Twelfth Amendment Act in August and this was ratified by a constitutional referendum on 15 September 1991.

In sum, the institutional framework for parliamentary democracy has been set up in Bangladesh. The Jatiya Sangsad, comprising directly-elected representatives of the people, has been the centrepiece of national politics; a cabinet, consisting of the leaders of the majority party, has been made accountable to the Sangsad. The prime minister, the primus inter pares, is head of the government. The constitutional head of state is the president, who is elected by the Sangsad. Steps have also been taken to institutionalise an independent judicial system.

Is the institutional framework good enough for sustaining democratic order in Bangladesh? How will the military react? In the face of the highly politicised armed forces, what is the future of democracy in Bangladesh? 


\section{The Nature of the Political System at Independence}

Bangladesh emerged as a sovereign state on 16 December 1971 after a bloodbath. The Awami League leaders, who led the independence movement, came to power. They had always favoured parliamentary democracy with real power vested in cabinet, collectively responsible to the legislature. A parliamentary form of government was introduced in Bangladesh according to the Provisional Constitution Order of 1972, and the political elite became the supreme policy makers. The 1972 constitution, which was passed by the Constituent Assembly on 4 November 1972, essentially continued the process. The major aspect of the 1972 constitution is the supremacy of the Jatiya Sangsad, comprising the directly elected representatives of the people, and a cabinet directly responsible to the Sangsad for its actions and policies.

The Awami League, which had massive popular support, became the ruling party. Although it was mainly a middle-class and urban-centred party, it had wellorganised student and labour fronts, and within a short period a number of groups oriented to the Awami League, such as the Jatiya Krishak League (National Peasants League) and the Jatiya Jubo League (National Youth League), were organised. These groups canvassed and mobilised support for the party and supplied policy and program inputs (Ahamed 1980:148-156).

An important trend under the Awami League regime was the gradual strengthening of political infrastructure at the administrative level. The senior advisers of Sheikh Mujibur Rahman were all political leaders. Those who accompanied him on tours both within and outside the country were mostly from the Awami League and party-affiliated interest groups. In the government, the party tried to consolidate its position. The office of the prime minister became the most powerful one in the government. In addition to having head offices and ministries for which the prime minister had specific responsibility, the prime minister's secretariat comprised offices of the principal secretary, political secretary, economic secretary and 'invigilation director'. The overall coordination of government activities at the administrative level was left to the principal secretary. To cap it all, the prime minister was Sheikh Mujibur Rahman, the president of the Awami League, a great charismatic leader, the symbol of Bengali nationalism a formidable 'Bangabandhu' (Friend of Bengal). Many observers felt that real power would remain concentrated in the hands of the political elite for a long time to come in Bangladesh.

The Awami League, despite its political approach and the use of party channels of control and direction, failed to handle the problems of increasing economic crisis, social and political instability, and deteriorating security and order in the 
country. As its failure became manifest, the regime began to turn to the bureaucrats. The bureaucrats who seemed to have lost their position of influence and power between 1972 and 1974 came to the forefront in the early months of 1975 and emerged as the ruling elite after August.

During the first few years after independence, the Awami League regime performed fairly well. It was able to avert a major economic crisis, mainly with the help of massive relief operations carried out by the United Nations Relief Operations in Bangladesh and other international agencies. Compared to the anarchic conditions of 1971 and early 1972, the law and order situation improved considerably. Indian troops were withdrawn by March 1972. The constitution was passed by the Constituent Assembly within nine months of independence, and general elections were held after only six months, according to the provisions of the new constitution. The Planning Commission brought out the First Five Year Plan within a year and a half. In all these matters the legend and charisma of Sheikh Mujib played a vital role (Ahamed 1980:149).

From January 1974, however, the economic situation in the country became critical. This was due partly to global inflation in 1972, and partly to the inefficiency and corruption of the leaders of the ruling party. Though 86 per cent of industries and 87 per cent of foreign trade were nationalised, distribution was conducted by private traders who were issued permits and licences. A substantial number of these permits and licences were issued to Awami League workers, who, in turn, sold them to traders, and consequently became the owners of large sums of 'unearned income'. Most of the administrators of the nationalised industries were recruited from amongst party leaders and workers who had very little knowledge of management or administration. Production, as a result, declined to an unusually low level. While production declined, the smuggling of jute and food grains to India reached alarming proportions, thus draining agricultural products out of the country. In the process, the economy was virtually in a state of collapse, and the situation was aggravated by the worst floods in Bangladesh history in July and August 1974. During the floods the price of consumer goods rose rapidly, and by September 1974 the rise was about 600 per cent over the 1969-70 price level. Sheikh Mujib declared that there was a "near famine condition' in the country (Ahamed 1980:151-52).

The economic crisis in Bangladesh was compounded by political problems. Class conflicts, which had for so long been subjugated by the demand for regional autonomy, emerged as the crucial problem. The real threat to political and social stability in Bangladesh during the Awami League regime came from the radical forces. They attempted to bring about a 'second revolution' through armed struggle. There were several radical revolutionary parties in Bangladesh; most 
of these had been working as underground organisations during the Ayub era (1958-1969). Some surfaced after independence.

They argued that the Bangladesh Revolution of 1971 was an 'unfinished one'. When the War of Independence was being transformed into a truly people's liberation war and the radical forces were coming to the forefront, the 'land-based bourgeois government of India' in league with the 'Soviet Social Imperialist Power' interfered, and the Awami League leadership, which represented the exploiting classes in Bangladesh, came to power. Their strategy was to replace the puppet regime by force (Maniruzzaman 1976).

The revolutionary parties trained armed cadres to overthrow the Awami League regime through guerrilla warfare, and started sabotaging communication links and killing Awami League leaders and other 'enemies' of the revolution. The exact number of secret political killings during that period is not known. One government estimate put the figure at over 6000, including four Awami League MPs. Along with secret killings, there was a sharp rise in armed robberies from private houses, looting of banks and shops, and attacks on police stations (Ahamed 1980:157).

The regime's initial response to the increasing violence consisted of threats, appeals and normal police action. In its attempts to combat radical political parties the Awami League relied mainly on party channels of control and direction, but this had limited success because the Awami League itself was plagued by factional strife. Soon after independence the Awami League's student and labour fronts were divided over the question of whether to introduce 'pure socialism' or a mixed economy. Senior leaders also became involved in the controversy, and the effectiveness of the party suffered greatly.

The factional strife was exacerbated first by Mujib's political approach to economic management, which led to the speedy growth of a new class of rich compradors, who were divorced from the forces of production. Further, Mujib's pragmatic approach to socialistic principles practically immobilised the party. To overcome this ineffectiveness, the Awami League formed an alliance with such less-radical parties as the National Awami Party (M) and the Pro-Soviet Bangladesh Communist Party. This alliance too proved ineffective, and Bangladesh slowly but steadily turned into a praetorian polity (Nordlinger 1977:7-8, 75-76).

The revolutionary forces could have been confronted by ideological clarity at the political level and by governmental performance at the societal level. The Awami League regime, however, failed on both counts: the political ideology of

$1 \quad$ Formulated by Sheikh Mujib's nephew, Sheikh Fazlul Huq Moni, Mujibism implied a variant of socialism with anti-imperialist but democratic overtones. 
Mujibism, ${ }^{1}$ which was initiated to counteract the radical forces, was not intellectually refreshing; its performance, especially after the famine of 1974, fell below expectations. For survival, the regime had to resort to repressive measures; that, however, proved counterproductive. As a last resort, the government declared a state of emergency on 28 December 1974 and suspended the fundamental rights granted by the constitution for an indefinite period. The emergency provided for special powers of arrest, curtailed the powers of the judiciary, and muzzled the press. In January 1975, on the initiative of Sheikh Mujib and reportedly against the wishes of most of the members of the Jatiya Sangsad, the constitution was amended to provide for a presidential form of government. Sheikh Mujib was subsequently vested with executive powers and authorised to declare Bangladesh a one-party state. Later Sheikh Mujib closed all but four newspapers, two English language and two Bengali. He also founded the national party, the Bangladesh Krishak Sramik Awami League (BAKSAL), patterned on Nyerere's Ujama (African Socialism).

In fact, this final act not only considerably reduced the support base of Mujib in Bangladesh but removed much of the legitimacy of his rule. The banning of the communal parties such as the Muslim League, Nizam-i-Islam, and Jamat-iIslam for their negative and anti-people role during the War of Independence alienated the rightist elements. The liberals favoured a Western-style parliamentary democracy; they were alienated when the Awami League regime adopted socialistic principles. When in the face of an acute economic crisis Mujib adopted a pragmatic approach, which considerably watered down his brand of socialism, the radical forces became antagonised. Even the young radicals of his own party left and formed a new party. The formation of BAKSAL was resented by both the liberals and radicals.

The precipitating factor for military intervention was, as suggested by several scholars, the personal grievances of the coup leaders, some of whom were dismissed by Mujib for performing duties ordered by him. The pre-dawn coup, which was staged on 15 August 1975 and eliminated most members of Mujib's family, except his two daughters, was masterminded by three majors who had developed bitter personal enmity against him. They captured power and declared on national radio 'the end of an era of tyranny' (Ahamed 1990).

\section{The Emergence of the Military as the Ruling Elite}

In a post-colonial state like Bangladesh the military tends to be dominant not only because these states have inherited an overdeveloped bureaucratic structure and its institutionalised practices, but also because of the nature of its institutional 
framework (Ahamed 1988:49-50). Organisation provides the armed forces with discipline and cohesion, hierarchy and centralised command; the institutional structure gives them power. It is no wonder therefore that the military became a dominant force in Bangladesh.

The armed forces of Bangladesh were not a well-knit establishment in the beginning, however, and could not emerge as a decisive factor in Bangladesh politics during the early years. This was due partly to the socio-political environment after independence and partly to internal schism and cleavages among the officer corps, which were effects of the bloody Independence War that continued from March to December 1971. The bureaucratic elite, both civil and military, was not held in high esteem in the society because of its association with military rule in Pakistan during the previous twelve years. Bureaucracy was in fact a much hated word in the political lexicon of Bangladesh. Sheikh Mujib often became livid with anger when he denounced bureaucracy. Moulana Bhasani, another prominent Bengali leader, did not complete a public speech without making a stinging attack on the bureaucracy.

Yet a large number of civil servants and military officers played a key role in the political struggle in the 1960s and in the Independence War. Many of them were aligned with the Awami League and personally remained on good terms with Sheikh Mujib during the Ayub era. Some of them supplied secret information to the Awami League leadership and provided data which helped Mujib to sharpen his case for regional autonomy. The Agartala Case, ${ }^{2}$ which was believed to have been staged in 1968 mainly to defame Mujib, implicated a number of civil servants and military officers.

Civil servants and military officers willingly lent their full support to Mujib's call for civil disobedience and non-cooperation, which paralysed the entire administration in East Pakistan in March 1971. When the Pakistan army launched its brutal attack on the night of 25 March, the Bengali military officer corps became one of the targets. During the Independence War military officers took responsibility for training the Mukti Bahini (Freedom Fighters) at various training centres both within and outside Bangladesh, and they themselves fought against the Pakistan army.

Despite this political role, the military could not consolidate its position after independence and did not emerge as a cohesive force for several reasons. In the

2 The Agartala Conspiracy Case, in which Sheikh Mujibur Rahman was charged along with thirty-four other Bengali politicians, civil servants and military officers with conspiring to bring about East Pakistan's secession in collusion with India, was initiated by the Pakistan Home Ministry on 6 January 1968. 
first place, the size of the armed forces was quite small. In 1975 there were about 36000 men in the defence services in Bangladesh, of whom 30000 were in the army, 500 in the navy and 5500 in the air force. In addition, there were 30000 men in the Bangladesh Rifles and 16000 in the Jatiya Rakkhi Bahini (National Security Force), which were paramilitary forces. Of those 36000 men, about 28000 (including 1000 officers) were 'repatriates' from West Pakistan; the remainder belonged to the former East Bengal Regiment and the new group recruited from amongst the Mukti Bahini. Though the number of officers was above 1200 in 1975, the number of officers above the rank of major was not more than 250 (Ahamed 1980:141).

While the size of the armed forces was small, the level of internal rivalry and cleavage was high. Conflicts between the Bangladesh Rifles and regular defence forces (former East Bengal Regiment) had continued since independence, and it assumed alarming proportions in 1972. Even the regular forces became involved in internecine conflicts. Some of the repatriate officers were either unceremoniously retired, or were placed under officers who were junior to them in the Pakistan defence forces but had been promoted for participating in the Independence War. The officers who took part in the Independence War were offered two years' seniority and treated preferentially. This differential treatment caused animosity among the freedom fighters and repatriates.

The repatriates regarded most of the freedom fighters as basically secularists, socialists and Pro-Indian, while the freedom fighters stereotyped the repatriates as opportunists and pro-Pakistanis. To the repatriates the War of Independence was fought with Indian resources and the victory was served by Indians to the Bengalis on a silver platter; to the freedom fighters, the repatriates basked in the Pakistani sun while the whole Bengali nation was locked in a life and death struggle. The freedom fighters, on the other hand, complained that repatriates were greedy enough to enjoy the fruits of independence without suffering for and contributing to it (Ahamed 1988:52-56).

The numerical superiority of the repatriates also made the freedom fighters feel insecure. The repatriates complained that they were not given full pay for the twenty-month period that they had to remain in the Pakistan concentration camp before being repatriated to Bangladesh in September 1973. This feeling of being discriminated against on the part of the repatriates, and consequent acrimony between the two groups, badly affected the morale of the military officers, accelerated the process of polarisation, and strained the command structure of the defence services. The armed forces in Bangladesh were also divided at the initial stage in terms of ideology. The repatriates retained much of the conservative outlook that characterised the armed forces in Pakistan, while the bulk of 
the freedom fighters were highly politicised and somewhat radical in their views. The two groups also held distinct views with regard to the institutional framework the armed forces should take in the future. One group favoured the retention of the conventional army on the pattern of British India or the Pakistan armed forces. The other group advocated that the armed forces be transformed into a kind of productive army on the pattern of the Chinese People's Army. A few officers, advocating this view, joined the underground wing of a political party, the Jatiya Samajtantrik Dal (JSD) and organised cells of the Biplobi Shainik Sangstha (the Revolutionary Soldiers Association) on the model of the Soviet of Soldiers which developed in the Tsarist army before the Communist Revolution in 1917. The two best-known advocates of the concept of productive army were the two valiant freedom fighters, Colonel Abu Taher and Colonel Ziauddin. These factors suggest that the armed forces in Bangladesh could not emerge as a decisive factor in politics at the beginning because of internal rivalry, ideological conflicts and intragroup feuds (Lifschulz 1979:85-88).

While the armed forces could not take advantage of their organisational strength, they could clearly perceive that their corporate interests were not safe in the hands of Awami League regime. The military elite resented the fact that the government did not take quick and effective measures for the reconstruction of the training institutes and cantonments destroyed during the Independence War. Consequently the defence services remained poorly equipped. Expenditure on defence services was not only minimal but was gradually reduced. In the 197374 budget, expenditure on defence was little more than 16 per cent; in 1974-75 it was reduced to 15 per cent, and in 1975-76 it was less than 13 per cent.

The establishment of a new militia, the Jatiya Rakkhi Bahini (National Security Force), organised under the direction of the prime minister's office and attached to the Awami League, introduced a parallel organisation to the regular armed forces. The government seemed to be more interested in the development of the militia than in the armed forces. It was planned that this militia would be increased annually so that by the end of 1980 its strength would be 20000 . It was also planned that one regiment of the Jatiya Rakkhi Bahini would be placed under the command of each district governor.

Most of the groups in the defence services in Bangladesh shared a common anti-Indian orientation. This was so for several reasons. First, most of the members of the armed forces who fought during the War of Independence strongly believed that the Indian Army just walked in when the war was nearly over at the end of 1971, thereby robbing the Bangladesh military of the glory of liberating their motherland. Second, many senior military officers believed that the government-in-exile at Mujibnagar signed a secret treaty with the Indian government, 
which was detrimental to the sovereignty of Bangladesh. They also believed that Sheikh Mujib became less interested in the development of the defence forces because of that treaty. Third, many senior army personnel felt that the Jatiya Rakkhi Bahini was planned and designed by the Indian Army for the safety of the Awami League regime. The poorly-equipped defence services were also bitter about the fact that the Indian Army took away all the sophisticated weapons left by the Pakistan Army. This anti-Indian feeling gradually developed into an antiMujib feeling because of Mujib's pro-Indian foreign policy.

Despite their grievances against the Awami League regime, the defence services in Bangladesh remained practically immobilised because of the schism and cleavages that affected them during the early years. When they were asked by the prime minister to go to the aid of the civil authorities, and conducted a number of successful operations, they not only regained their sense of unity and cohesion but also came to believe that their services were indispensable. From July 1973 to July 1974 there was a number of combined military operations between the Rakkhi Bahini and the police, such as checking for smuggling at the border, handling 'extremists', and maintaining law and order. As internal threats mounted, and were successfully managed, the military officers began to believe that only the Bangladesh Army could save the country. Officers' growing participation in the day-to-day affairs of the state made them not only sensitive to political power but also aware of the basic weaknesses of the regime, particularly the corrupt practices of some top ranking leaders, and of their unpopularity. Thus when a pre-dawn coup was staged on 15 August 1975 by a handful of junior officers (twenty to twenty-five majors and captains) with the help of two battalions of the armored corps and 1500 soldiers, it came as no great surprise.

The August 1975 coup paved the way for the emergence of the military as the ruling elite. The Zia regime (1975-1981) helped them, albeit unwittingly, to attain a new height of maturity; the Ershad regime turned out to be a period of consolidation. The August coup may be regarded as a pacesetter in that it was closely followed by a series of counter coups or coup attempts. The seeds of all those were sown in the August putsch.

The 3 November coup was essentially a pre-emptive bid to prevent the radical forces from taking over control of the armed forces. It, however, failed to take roots. Khaled Mosharraf and the other ringleaders were overwhelmed by the 7 November Soldiers' Uprising, which in effect catapulted Major General Ziaur Rahman to political power.

General Zia, having assumed power by default rather than by design, was confronted by serious problems from his own constituency: the highly politicised army. Though before the 7 November uprising Zia was the recognised leader of 
the freedom fighters and as such was highly respected and loved by his comradesin-arms, he had something of a falling out with them after the death of Colonel Taher (who was arrested, subjected to a prison trial and hanged on Zia's orders), because Taher was mainly instrumental in organising what happened on 7 November. Then Zia turned to the repatriates and managed to strike a balance between the freedom fighters and repatriate officers of the defence services.

As a soldier, Zia's loyalty to and reliance on the military was deep. Unlike his predecessor, Sheikh Mujibur Rahman, who kept political elements separate from the military, Zia pursued a policy of welding these together and tried to incorporate military personnel into different sectors of national life. The salary of both the jawans (privates) and officers was enhanced; the system of rent payment for accommodation was modified to their benefit; and Zia created openings for the assignment of retired military officers to lucrative jobs in other sectors.

On 1 March 1979, 25 of the 625 officers in the senior policy pool, responsible for policy-making in the secretariat, were military officers. Of 101 chairmen or managing directors of public corporations in June 1980, 42 were military officers or retired serviceman. In January 1981, 22 of the 40 district superintendents and additional superintendents of police were army officers. Moreover, 500 retired military officers were employed in industry, indenting business, foreign trade, and supply and contracts under the patronage of the government. Quite a few military officers were allotted residential plots in the developed areas of the city, and were even granted liberal loans for building houses by the House Building Finance Corporation. With all of these actions, Zia's critics argued, he was consciously following the Indonesian model of partnership between the military and civilian sectors: civilians being the junior partners (Ahamed 1988:124-25).

General Zia laid the foundations of a number of civilian institutions such as the Bangladesh Nationalist Party (BNP), and Gram Sarker (village government). He also initiated a number of participatory programs such as canal digging and eradicating illiteracy through literacy squads which were established in early 1979. He introduced a multi-party system in the country, and before the presidential elections in June 1978, when he was elected president of the country, Zia resigned from the post of the chief of army staff. During his time, general elections were held in February 1979 to form the Jatiya Sangsad. A process of civilianisation was launched by President Zia in late 1977. One can, however, argue that the civilianisation process culminated in the primacy of the military. One of the reasons why Zia was killed in the abortive coup of 30 May 1981, some scholars have argued, was his 'over-democratising' of the political system. The measures taken by Zia not only raised the expectations of the military, but gave them a stake in the polity. The military thus emerged in the 1980s as a 
powerful socio-economic group, much more confident than any other sector in Bangladesh society.

This political consciousness of the military began to take shape at two levels during the Ershad regime. Deeply entrenched at the centre of power, they could not afford to be indifferent to the forces shaping politico-economic decisions at the highest level, and thus became positively involved in a process which was expressly political. Second, from the early 1980s they began demanding a constitutionally-incorporated active role in the governance of the country (New York Times 14 November 1981).

The military, if it had wanted, could have seized political power in the wake of the Chittagong coup of 30 May; however it refrained from doing so for good reasons. The senseless and dastardly assassination of Zia by a section of the armed forces not only endeared $\mathrm{Zia}$ to the nation but also created a kind of abhorrence towards men-in-uniform. The repatriate generals under the leadership of General H.M. Ershad weighed this carefully, and by way of buying time lent support to the constitutional change of government. The generals also knew that the viability of the successor government during a period of uncertainty could be ensured largely through their support. Thus they extended liberal support to the Sattar government, ensuring continued military domination over the policymaking structure.

Justice Abdus Sattar, the 75-year old successor to Zia, in his campaign speeches for the November 1981 presidential elections, emphasised among other things his close association with the late president and as such his enjoyment of the trust and respect of the country's armed forces (Ahamed 1988:132). The military elite thus threw their weight behind Justice Sattar's candidature. Zia's policy of fusing the upper echelons of the bureaucracy and the military into the bedrock of a stable political system was endorsed by the military. Moreover, the structural weaknesses of the Bangladesh Nationalist Party (BNP), an outcome of Zia's 'open arms policy' of welcoming divergent political elements ranging from the progressive left to the fundamentalist right, were also perceived by the military as advantageous to their corporate interests. The BNP, which had been held together mainly by Zia's charismatic personality and political power, was likely to yield wider scope for bargaining to the military after the death of its leader.

Though the corporate interests of the military remained the crucial factor, internal dissension and factional cleavages within the ruling party provided the sought-after occasion for the generals. The BNP was developed rapidly by its leader, General Zia, mainly with a view to extending his power base beyond the cantonments. While he was alive, factional cleavages did not surface. His sad demise, however, seemed to have lifted the lid, leading to a sudden outburst of 
conflicting views and interests, and the proliferation of antagonism and dissidence within the BNP. Thus, within a year of Zia's death, the Bangladesh polity verged on the brink of praetorianism (Perlmutter 1977:104-107). It was anybody's guess whether the military, which emerged as a well-knit and self-confident force after the Chittagong incident, would assume political power at an opportune moment. The generals did not have to wait long; only four months after the landslide victory of Justice Sattar in the presidential elections of 1981, Bangladesh experienced a bloodless coup. The military, under General H.M. Ershad, wielded political power from then until 6 December 1990, when a violent popular uprising forced Ershad to resign.

\section{Politicisation of the Armed Forces}

A high level of politicisation of the armed forces is evident in Bangladesh. The 15 August 1975 coup, by a handful of junior officers with the help of two battalions of armoured corps, was the first indication of the armed forces' overt intention to play a political role. It was followed by a series of coups and countercoups until 30 May 1981 when General Zia was brutally killed by a group of about twenty mid-level officers at Chittagong in another abortive coup. Bangladesh was placed under martial law for the second time under Lieutenant General H.M. Ershad from March 1982 to November 1986. The military-dominated civilian regime remained in power until December 1990.

The military ruled Bangladesh for more than nine of the twenty years of its independent existence; another four years were under the shadow of martial law, with men-in-uniform in the background. What is more significant is that the military not only assumed a political role, but claimed that they had a right to do so. Before the assumption of power in March 1982, Major General Ershad demanded that the military be accorded a constitutional role to ensure the protection of the political system (Ershad 1981:12; New York Times 14 November 1981).

The process of politicisation of the armed forces in the post-colonial state of Bangladesh is linked with the organisational framework of the military in British India and the orientation of its officer corps. In Western countries the concept of the military as a more or less politically neutral body has emerged mainly because democratic institutions have evolved over a longer period of time with little involvement of the military. Moreover, as an apparatus of the state, military organisations were designed mainly to handle external defence. The British Indian Army, which was the predecessor of the armed forces of all the South Asian states, was by contrast trained from its very inception to be 'the custodian of law and order' with a view to promoting imperial interests. It was thus essentially in 
opposition to the national interest and demands, and its organisation was always subject to political considerations. The roots of politicisation of the armed forces can therefore be traced to this peculiar conception of its role.

For the supreme purpose of securing and perpetuating colonial interests in India, the British army's policy had been to capitalise on existing religious antagonisms between the minorities through a policy of 'divide and rule'. The British Indian military's deployment strategy was based on the dictum: 'Keep your Sikh regiments in the Punjab, and they will be ready to act against the Hindoos; keep your Hindoos out of the Punjab and they will be ready to act against the Sikhs' (Philip 1962: 508).

With the nationalist movement gaining ground increasingly in India from the latter part of the 19th century, an intense effort was made by the colonial government to indoctrinate Indian troops in general and the officer corps in particular with an anti-political and anti-democratic orientation. They were taught that politicians were no more than 'rabble rousers' and 'disruptionists', and that their activities merely undermined the social order and systemic solidarity. Thus the British Indian military officers in the course of time were not only thoroughly anglicised but also rendered anti-national, anti-political and anti-democratic.

Analysing this aspect of the British Indian military, many scholars came to believe that among military officers assimilation displayed itself not merely in 'the exquisitely tailored lounge suits of officers in mufti, in a penchant for understatement, for beautiful silver, and for cavalry moustaches', but also in their belief that politicians were no more than 'scallywags' (Rudolph and Rudolph 1964).

After independence, the organisation of the armed forces in India, and their systems of training and recruitment, underwent profound changes; but the armed forces in Pakistan continued to be organised and trained on basically the same lines as in British India (Khan 1963:220-235). A general headquarters (GHQ) was set up as the central agency responsible for the administrative affairs of the various defence services. Training institutions such as the Pakistan Military Academy or Air Force Academy were established on the same lines as at Sandhurst in Britain and Dehradun in India. The new military leaders continued to be recruited from the same bases; the armed services personnel continued to remain in the cantonments, which were physically and culturally distanced from the civilian sectors, having a sense of being a part and yet apart from the society in which they lived (Alavi 1966). This duality in attitudes of the soldiers towards their society and their professional expertise created an ambivalence in their attitude towards the political institutions in Pakistan. The root causes of the martial law clamp-down in Pakistan in 1958 can be traced to the dynamics which were generated in the Pakistan Army because of training, organisation and the 
orientation of its officer corps.

After the conclusion of the Mutual Defence Assistance Agreement with the US in 1954, the Pakistan Army acquired sophisticated American military technology. Acquisition of new technology enhanced not only the Pakistan military's striking power but also its bargaining strength. Soon after, it began to penetrate the civilian government of Pakistan. Thus, ultimately by staging a coup and assuming dictatorial powers in 1958, General Ayub Khan established the supremacy of the men-in-uniform in Pakistan.

Most of the Bengali military officers, who played crucial roles in seizing political power in Bangladesh in the 1970s, were recruited during this period and were trained and socialised under the shadow of Ayub Khan's martial law regime. The proclamation of martial law in 1958 had far-reaching effects on the Bengali military officers in many ways. Officers became conscious of the role the military could play in the political system; they also became sensitive to political power. They became conscious of the regional imbalance in the armed forces, too, and they began to realise that the Bengali officers in the Pakistan Army were not accorded equal treatment. Bengali officers also felt that a policy of discrimination was practised against them in matters of pay, promotion and other perquisites. These discriminatory policies made the Bengali officers not only resentful, but also vociferous in their complaints against the West Pakistani ruling elite. In the 1960s their complaints became louder when by default Bengali bureaucrats, both civil and military, became the chief spokesmen for Bengali interests in the absence of free political processes. This role politicised them further. The Agartala conspiracy case bears ample testimony (Ahmed 1991:91110).

The most important factor in the intense politicisation of the Bangladesh armed forces was the War of Independence of 1971. The fact that a large number of officers and jawans, throwing aside their professional norms and indignantly breaking the canons of military discipline and chain of command, rose against the establishment and joined the war, was itself a revolutionary step. Under normal circumstances, all of them would have been court-martialed, but after independence they became war heroes and were greeted with warm-hearted glee and pride by the nation. Moreover, the new strategy of guerrilla warfare, devised in a conference of sector commanders at Teliapara in July 1971, had the double effect of further politicising the armed forces and radicalising them to a great extent (Ahamed $1988: 43-45$ ).

In sum, the Bangladesh Army, which was the lineal descendant of the British Indian and Pakistan Army, inherited not only the institutional framework of its predecessors but also their orientation against civilian rule and their sensitivity 
to political power. The War of Independence removed the distance between the civilians and armed forces personnel, and made them aware of the nature of weak political leadership and fragile political institutions.

\section{Popular Attitudes to Democracy}

Though the armed forces in Bangladesh have been highly politicised, the people of South Asia have been deeply committed to democratic order. During the British rule in India, Bengalis were in the forefront of democratic movements in the 1920s and 1930s. The All-India National Congress and the Muslim League, which had been mainly responsible for the partition of India and Pakistan, were led by Bengali political leaders in the formative phases. The freedom movement in British India, in a sense, was a movement for a democratic polity and was deeply rooted in the democratic ethos.

The Lahore Resolution of 1940 appealed to the people of East Bengal mainly because of its democratic overtones: it espoused the principle of national selfdetermination; it also laid stress on internal autonomy. Pakistan came into being in 1947 on the basis of the Lahore Resolution. The continuance and full flowering of parliamentary democracy became the pet demands of the East Pakistanis after that, and most of their movements were firmly grounded in democratic ideals. Seven of the historic twenty-one points of the United Front, a grand coalition of the opposition political parties in East Pakistan organised with a view to focusing their demands and fighting the ruling Muslim League in the 1954 provincial elections, were closely related to the proper functioning of the parliamentary system in East Pakistan (Jahan 1972:45-47).

The famous Six-Point Program, which ultimately led to a full-fledged nationalist movement among Bengalis in the late 1960s, began with a call for the establishment of a federation in Pakistan on the basis of the Lahore Resolution; it also demanded a parliamentary form of government with the supremacy of the national assembly, directly elected by the people on the basis of universal adult suffrage (Ahamed 1989:32-43). The main motivating force for Bengali involvement in the War of Independence in 1971 was their desire for a democratic system, a desire blatantly denied by the Pakistani ruling elite during the postelection years.

But while the people of Bangladesh are committed to a democratic order, the political parties, which are the positive instruments for a working democratic system, are not yet properly prepared for the job. Though Bangladesh has scores of political parties, only a handful of these are institutionalised, well-knit and organised at the grassroots level, and having definite policies and programs of 
action. This is due partly to political history and tradition and partly to the socioeconomic structure of the country.

In South Asia political parties have never been decisive instruments for framing public policy or for projecting alternatives. Except for short interludes, moreover, political parties have had few opportunities for functioning openly since competitive politics has been restricted. During the colonial period political structures were merely embryonic, and their operations were mostly extra-legal. Even after independence in 1947 the ruling elite continued to maintain many of the restrictions which had been imposed on the free flow of political activities during the colonial period. During military rule, political parties and party activities were usually the first casualties.

Democracy is essentially a system of alternative programs and policies propagated by political parties. When a particular set of programs and policies fails to command the support of the people alternative programs and policies are tried. Elections are formal procedures to choose programs and policies at a particular point in time. Bangladesh has, however, inherited a political tradition where mass movements and elections are entwined. During the last four decades there were a number of political movements, which crystallised certain issues and mobilised political forces. Elections were then held, not to choose between the alternative programs and policies, but merely to pick the winning political forces.

Though a vast majority of voters participated in these elections, they took sides not merely as party supporters but also as supporters of the crucial political movements; some of these took the form of national movements. These elections, strictly speaking, became plebiscites. The election of 1946 on the Pakistan issue, the 1954 elections on the autonomy question, the elections of 1970 on the basis of the Six-Point Program, and those of 1991 under the caretaker government were meant to serve other functions; they were more legitimising plebiscites than elections. Each was unique, and had distinct appeals to the voters.

Not only is the political history and tradition not congenial to the growth of a stable party system in Bangladesh, but neither are the socio-economic conditions. The endemic poverty of the people, intense factionalism among the various social groups and classes, and a network of patron-client relationships reaching from the grassroots to the central politico-bureaucratic elites at the national level, have resulted not only in organisational weakness and a very low level of institutionalisation in the polity, but also in institutional fragmentation.

Under such circumstances no political party can serve as the effective allocator of values or platforms for conflict resolution or a meaningful focus of civic loyalty. Political loyalty has been directed to persons, to the loci of patronage. Since political loyalty has been channelled towards patrons or centres of patronage, 
persons who can seize the principal patron roles and sustain the flow of material benefits to the clients are likely to receive the conditional allegiance and support of the client network. That explains why some of the opposition leaders change their position overnight and become staunch supporters even of a regime dominated by the military. A political party cannot retain the support of a substantial portion of the voters and remain underdeveloped.

\section{Prospects for Democracy and the Role of the Military}

Analysing all these factors, some scholars at home and abroad have suggested that the Bangladesh polity might well be on the road to persistent praetorianism with an occasional civilian-military façade (Baxter and Rahman 1991:59). The popular uprising of 1990, with the direct participation of most of the political parties in Bangladesh, and subsequent events, however, give grounds for optimism. Though Bangladesh has yet to build a political system based on consensus and compromise, it has come a long distance in that direction.

The political parties, despite their stunted growth and lack of institutionalisation, have now arrived at a consensus on the nature of the political system in the country. Nothing short of a representative parliament is acceptable. The government must be accountable to the parliament. The judicial branch must be independent as the bulwark of basic human rights. The press must be free. The consensus has been evident in the rejection of seven-party and five-party alliances to participate in either of the Sangsad elections under Ershad and also in the eight-party alliance's refusal to take part in the 1988 Sangsad election. ${ }^{3}$

These demands, having been repeatedly voiced from different party platforms during the last decade, became the core of the consensual agreement reached by the three political alliances on 19 November 1990. These alliances, working as the motivational force behind the popular uprising, were instrumental in bringing it to its logical conclusion on 6 December 1990. In a society characterised by endemic violence and intense factionalism, thanks to the willing co-

3 Most of the political parties which were opposed to General Ershad's usurpation of political power and his autocratic rule formed two alliances in 1983: a fifteenparty alliance centred on the Awami League, and a seven-party alliance centred on the Bangladesh Nationalist Party (BNP). On the issue of participation in the 1986 general election the fifteen-party alliance broke up, forming an eight-party alliance centred on the Awami League, and a left-leaning five-party alliance. These three alliances played a crucial role in ousting General Ershad from power in December 1990. 
operation of all the political parties the general election of February 1991 turned out to be absolutely free, fair, neutral and peaceful. The Twelfth Amendment Act, reintroducing the parliamentary system of government, was enacted in an environment of unprecedented cordiality among the political parties on 6 August 1991. The parliamentary committees of the fifth Sangsad, designed to institutionalise parliamentary control over the different ministries, have started functioning.

The orientation of the armed forces in Bangladesh also seems to have undergone some change. They treated the movement against Ershad from October to December 1990 as a political problem and wanted it to be solved politically, General Ershad's insinuation of a more active role for them notwithstanding. Most coups are internally generated by local cleavages and power conflicts, but external encouragement or discouragement can be crucial to their success or failure. In Bangladesh, American assistance has been of crucial importance to the success of the post- Mujib regimes, and the 15 August 1975 coup was a turning point in the warming of Bangladesh-US relations. The triumph of democratic order globally, and especially in South Asia, may help further deepen the changing orientation of the armed forces in Bangladesh.

An alternation of military and military-dominated civilian regimes in Bangladesh thus may not be the only prospect. A democratic order is more likely to strike its roots into the political soil of Bangladesh if the political parties can maintain the emerging consensus and politics of compromise. 